Agroradix Vol. 3 No.1 Desember (2019)

ISSN : 2621-0665

\title{
Kajian Macam Media Tanam dan Dosis Pupuk Hayati Terhadap Pertumbuhan Bibit Tanaman Tebu (Saccharum officinarum L.)
}

\author{
Mariyatul Qibtiyah, Ashifa Firman Wahyudi, dan Choirul Anam \\ Prodi Agroteknologi Fakultas Pertanian Universitas Islam Darul ‘Ulum Lamongan, Jawa Timur \\ Korespondensi : mariyatulqibtiyah@unisda.ac.id
}

\begin{abstract}
ABSTRAK
Tanaman tebu adalah tanaman tropis yang sangat penting karena dapat digunakan bahan baku untuk pembuatan gula. Usaha peningkatan kualitas produksi tanaman tebu secara tepat sasaran, Salah satunya adalah perbanyakan tanaman berupa bibit, Kultur teknis atau perawatan bibit dengan jalan pemupukan diawal waktu pembibitan dan komposisi media tanam. Tujuan penelitian ini adalah untuk mengetahui pengaruh macam media tanam dan dosis pupuk hayati terhadap pembibitan tanaman tebu (Saccharum officinarum L.). Penelitian ini dilaksanakan di Desa Kedungbunder, Kecamatan Mantup, Kabupaten Lamongan. Penelitian menggunakan Rancangan Acak Kelompok (RAK) faktorial dengan dua faktor perlakuan yaitu Macam Media Tanam (T) dan Dosis Pupuk Hayati (H). Faktor Macam Media Tanam Terdiri dari 3 perlakuan yaitu: Tanah (TO), Tanah + Pupuk Kandang Sapi (T1), Tanah + Pasir + Pupuk Kandang Sapi (T2). Faktor Dosis Pupuk Hayati terdiri dari 3 level yaitu: Tanpa Pupuk Hayati (H0), Pupuk Hayati 10 g/tanaman (H1), dan Pupuk Hayati 15 g/tanaman (H2). Indikator pengamatan meliputi: Tinggi Tanaman, Diameter Bibit, Jumlah Anakan, Bobot Segar Bibit, Bobot Kering Bibit. Terdapat interaksi antara perlakuan macam media tanam dan dosis pupuk hayati. Kombinasi perlakuan terbaik adalah $\mathrm{T} 1 \mathrm{H} 2$ (tanah + pupuk kandang sapi dan pupuk hayati $15 \mathrm{~g} /$ tanaman) pada parameter tinggi tanaman dan diameter bibit. Perlakuan macam media tanam berpengaruh baik pada hampir seluruh parameter pengamatan. Dosis pupuk hayati berpengaruh terhadap tinggi tanaman, diameter bibit, bobot segar bibit, bobot kering bibit.
\end{abstract}

Kata kunci : Pupuk hayati,tanah, pasir,pupuk kandang sapi, tebu

\section{ABSTRACT}

Sugar cane is a tropical plant that is very important because raw materials can be used to make sugar. Efforts to improve the quality of sugar cane production in a targeted manner $i$, one of which is to multiply plants in the form of seeds, technical culture or nursery care by fertilizing at the beginning of the nursery and the composition of the planting medium. The purpose of this study was to determine tge effect of the types of planting media and doses of biological fertilizing on sugarcane nursery (Saccharum officinarum L.). This research was conducted in Kedungbunder Village, Mantup Sub-district, lamongan District. This study used a trandomized block design (RAK) factorial with with two treatment factors namely the type of planting media (T) and doses of woody fertilizer $(\mathrm{H})$. Factor such as planting media consist of 3 treatments namely : soil (TO) soil + cow manure (T1), soil + sand + cow manure (t2). Boifertilizer dosage factor consists of 3 levels, namely : whithout fertilizer (H0) biological fertilizer $10 \mathrm{~g} /$ plant (H1), biological fertilizer $15 \mathrm{~g} / \mathrm{plant}(\mathrm{H} 2)$. Observation indicators include: plant height, seed diameter, number of tillers, seed fresh weight, seed dry weight.There is an interaction between the treatment of various types of planting media and dioses of biological fertilizers. The best treatment combination is $\mathrm{T} 1 \mathrm{H} 2$ ( soil + cow manure and $15 \mathrm{~g} /$ plant fertilizer) in parameters of plant height ad seed diameter. The type of treatment of planting media has a good effect on almost all observational parameters. Doses of biofertilizer have an effect on bothplant height, seed diameter, seed fresh weight, seed dry weight.

Key words : biological fertilizer, soil, sand, cow manure, sugar cane 


\section{PENDAHULUAN}

Tanaman tebu di daerah beriklim tropis dapat tumbuh baik dan termasuk golongan rumput-rumputan. Tanaman tebu di bidang perkebunan termasuk tanaman utama. Pembudidayaan tebu terdapat banyak di Indonesia khususnya pulau Jawa dan Sumatra. Sebelum masehi tanaman tebu sudah dikenal dan setiap tahunnya tanaman pemanis ini dapat menghasilkan 27 juta ton. Batang tebu terdiri dari komponen seperti monosakarida $0,5-1,5 \%$, sukrosa $11-19 \%$, zat organik 0,5 $1,5 \%$, zat anorganik 0,15\%, air $65-75 \%$, dan bahan lainya 12\% (Primahandana 2008).

Usaha peningkatan kualitas produksi tanaman tebu secara tepat agar sasaran, Salah satunya adalah perbanyakan tanaman berupa bibit, Kultur teknis atau perawatan bibit dengan jalan pemupukan diawal waktu pembibitan (Khaswarina, 2011). Tujuan utama dari pembibitan yaitu untuk menyediakan kualitas bibit dengan kriteria kokoh, sehat dan kuat. Hal tersebut merupakan faktor penentu keberhasilan penanaman di lahan untuk mendapatkan pertumbuhan yang baik. Sebagaimana dijelaskan oleh Setyamidjajan (2006) bahwa tujuan dari pembibitan yaitu untuk mendapatkan bibit yang seragam dan bebas dari bibit yang tidak sempurna sehingga diperoleh bibit dengan kualitas baik.

Sebagai media tanam tanah subur yaitu tanah yang memiliki profil melebihi 150 $\mathrm{cm}$, pH 6-6,5 dengan aktivitas jasad renik tinggi, struktur remah gembur, kandungan unsur hara cukup dan tidak ada pembatas tanah untuk pertumbuhan tanaman. Media tanam merupakan tempat berkembangnya akar dan dapat menyediakan unsur hara yang dibutuhkan tanaman. Media tanam sangat penting untuk menunjang pertumbuhan tanaman, melalui media tanam sebagian unsur hara dipasok selanjutnya oleh akar diserap untuk digunakan proses fisiologis tanaman. Hasil Penelitian (Sriyanto., et al., 2015) Komposisi tanah + pupuk kandang sapi + pasir dengan dosis pupuk nitrogen $150 \mathrm{~kg}$ memiliki bobot per tanaman dan per buah paling tinggi. Pemberian pupuk kandang sapi menghasilkan berat buah terung lebih tinggi dibandingkan dengan tanpa pemberian pupuk kandang sapi. Hal ini disebabkan karena pemberian pupuk kandang sapi, unsur hara yang dibutuhkan tanaman dapat terpenuhi karena terjadi perbaikan sifat dan biologis tanah.

Media tanam mempunyai sifat fisik yaitu lembab, berpori, dan draenase baik. Campuran media tanam perlu menghasilkan susunan yang sesuai karena memilikii pengaruh berbeda untuk tanaman. Sejalan dengan pendapat Sutejo (1992) pemberian bahan organik seperti pupuk kandang, kompos atau bahan organik lain dapat memperbaiki tanah.Selain macam media tanam pemupukan juga diperlukan terutama untuk mengatasi gejala kekurangan unsur hara.

Pupuk hayati adalah pupuk yang dapat membantu menyuburkan tanah dan berperan positif untuk tanaman. sejalan dengan pendapat Mezuan et al., (2002) bahwa aktivitas biologi yang terdapat dalam pupuk hayati dapat membantu kesuburan tanah. Menurut Hanafiah et al., (2007) mikroba yang selalu digunakan dalam pertanian yaitu mikroba menambat Nitrogen di udara, merangsang pertumbuhan dan melarutkan hara (terutama $\mathrm{P}$ dan $\mathrm{K}$ ). Tujuan Penelitian ini untuk mengetahui pengaruh macam media tanam dan dosis pupuk hayati terhadap pembibitan tanaman tebu (Saccharum officinarum L.). 
ISSN : 2621-0665

\section{METODOLOGI PENELITIAN}

\section{Tempat dan Waktu}

Penelitian ini dilaksanakan di Desa

Kedungbunder, Kecamatan Mantup, Kabupaten Lamongan. Ketinggian tempat \pm 10 meter di atas permukaan laut (mdpl). Pelaksanaan penelitian pada bulan Januari sampai April 2019.

\section{Alat dan Bahan}

Alat yang digunakan dalam penelitian ini, antara lain: Tray, Sprayer, Sabit, Meteran, Papan Nama, Jangka Sorong, Kamera, Timbangan, Alat Tulis.

Bahan yang digunakan dalam penelitian ini adalah benih varietas BL (bululawang), Tanah, Pasir, Pupuk Kandang sapi, Pupuk Hayati (potensida), Pestisida pengendali hama dan penyakit.

\section{Metode Penelitian}

Penelitian menggunakan Rancangan Acak Kelompok (RAK). Penelitian terdiri atas dua faktor perlakuan, faktor pertama yaitu Macam Media Tanam terdiri dari : T0 (Tanah); T1 (Tanah + Pupuk kandang Sapi); T2 (Tanah + pupuk kandang sapi + pasir), faktor kedua yaitu Dosis Pupuk Hayati yang terdiri dari : HO (Kontrol); H1 (10 gram/tanaman); H2 (15 gram/tanaman).

\section{Pelaksanaan Penelitian}

\section{Pembuatan Media Tanam}

Tanah yang digunakan adalah tanah top soil, kemudian dicampur dengan pasir dan pupuk kandang sapi yang telah disiapkan sesuai dengan taraf yang telah ditetapkan yaitu M0 hanya menggunakan tanah, M1 ( tanah dan pupuk kandang sapi 1 :1), M2 ( tanah, pasir dan pupuk kandang sapi $1: 1: 1$ ). Kemudian media tanam dimasukkan kedalam tray.

\section{Persiapan bibit}

Bibit yang dihasilkan dari kebun berupa pucuk (rayungan) dan bagal. Untuk memperoleh bibit dengan kualitas yang baik maka bibit dipungut pada umur tanaman antara 6 bulan. Tebu bagal dipotong-potong dengan mengunakan gergaji kayu. Setiap potongan tebu terdiri dari satu mata tunas. Setelah tebu dipotong-potong direndam dengan cairan ZPT untuk memacu perkecambahan.

\section{Tanam Pindah Tray}

Bibit tebu setelah umur 15 hari siap dipindah tanam kedalam tray. Setiap lubang tray ditambah pupuk phonska 4 butir per lubang tray.

\section{Pengairan}

Pengaturan air perlu dilakukan sejak penyiapan tempat, menjelang dan sesudah penanaman serta selama pemeliharaan. Apabila musim hujan draenase perlu mendapat perhatian. Penyiraman saat tanam tidak berlebihan, karena dapat merusak struktur tanah. Sebaliknya tidak terlalu kering karena bisa menghambat pertumbuhan tebu.

\section{Pemupukan}

Pupuk hayati diberikan dengan konsentrasi HO (Kontrol), H1 (10 g/tanaman), H2 (15 g/tanaman). Pemupukan dilakukan 10 hari sekali selama 3 bulan. Pengaplikasian pupuk baik pupuk organik maupun anorganik dilakukan dengan meletakkan pupuk pada daerah perakaran tanaman tebu.

\section{Pengendalian Hama Dan Penyakit}

Pengendalian hama penyakit secara menyeluruh dilakukan prinsip pengendalian hama terpadu. Penerapan dilakukan secara berkesinambungan.

\section{Pengamatan dan Pengolahan Data}

Pengamatan dilakukan setelah 2 minggu bibit tanaman tebu dipindahkan kedalam tray, pengamatan dilakukan hingga tanaman berumur kurang lebih 3 bulan, 
Agroradix Vol. 3 No.1 Desember (2019)

ISSN : 2621-0665

karena pembibitan dengan metode bud chip hanya membutuhkan waktu 3 bulan sampai bibit siap tanam. Parameter yang diamati yaitu parameter pertumbuhan (Fase vegetatif) meliputi: Tinggi Tanaman, Diameter Bibit, Jumlah anakan, Bobot segar bibit, Bobot kering bibit. Data pengamatan dianalisa dengan uji Fhisher (uji $F$ taraf 5\% dan 1\%) apabila terdapat perbedaan nyata dilanjutkan dengan uji Beda Nyata Terkecil (BNT 5\%).

\section{HASIL DAN PEMBAHASAN}

Tinggi Tanaman

Hasil analisa ragam menunjukkan adanya interaksi antara perlakuan macam media tanam dan dosis pupuk hayati terhadap parameter tinggi tanaman pada pengamatan umur 56 hst, 70 hst dan 84 hst. Sedangkan pada pengamatan umur 14 hst, 21 hst dan 42 hst tidak terdapat interaksi. Rata-rata tinggi tanaman terdapat pada Tabel 1.

Tabel 1. Rata-rata Tinggi Tanaman (cm) pada Umur 56 Hst, 70 Hst dan 84 Hst.

\begin{tabular}{|c|c|c|c|}
\hline \multirow[t]{2}{*}{ Perlakuan } & \multicolumn{3}{|c|}{$\begin{array}{l}\text { Rata-rata Tinggi Tanaman (cm) } \\
\text { pada Pengamatan Umur ke }\end{array}$} \\
\hline & $56 \mathrm{Hst}$ & $70 \mathrm{Hst}$ & $84 \mathrm{Hst}$ \\
\hline Tanah,pupuk hayati $0 \mathrm{~g} /$ tanaman & $15,51 \mathrm{~d}$ & $18,64 \mathrm{bc}$ & $21,11 \mathrm{bc}$ \\
\hline Tanah,pupuk hayati $10 \mathrm{~g} /$ tanaman & $15,91 \mathrm{bcd}$ & $17,81 \mathrm{c}$ & $20,52 c$ \\
\hline Tanah,pupuk hayati $15 \mathrm{~g} /$ tanaman & $16,18 \mathrm{bcd}$ & $17,93 \mathrm{c}$ & $20,63 \mathrm{c}$ \\
\hline Tanah,pupuk kandang sapi,pupuk hayati $0 \mathrm{~g} /$ tanaman & $15,67 \mathrm{~cd}$ & $18,21 \mathrm{bc}$ & $20,89 \mathrm{bc}$ \\
\hline Tanah,pupuk kandang sapi,pupuk hayati $10 \mathrm{~g} /$ tanaman & $16,09 \mathrm{bcd}$ & $18,71 \mathrm{bc}$ & $20,84 \mathrm{bc}$ \\
\hline Tanah,pupuk kandang sapi,pupuk hayati $15 \mathrm{~g} /$ tanaman & 17,37 a & $20,10 \mathrm{a}$ & $22,91 \mathrm{a}$ \\
\hline Tanah,pasir,pupuk kandang sapi, pupuk hayati $0 \mathrm{~g} /$ tanaman & $16,45 b$ & $18,01 \mathrm{c}$ & $20,54 \mathrm{c}$ \\
\hline Tanah,pasir,pupuk kandang sapi,pupuk hayati $10 \mathrm{~g} /$ tanaman & $15,85 \mathrm{bcd}$ & $18,27 \mathrm{bc}$ & $20,78 \mathrm{bc}$ \\
\hline Tanah,pasir,pupuk kandang sapi,pupuk hayati $15 \mathrm{~g} /$ tanaman & $16,39 \mathrm{bc}$ & $19,17 a b$ & $21,63 \mathrm{~b}$ \\
\hline BNT 5\% & 0,74 & 0,97 & 0,94 \\
\hline
\end{tabular}

Keterangan : Angka-angka yang diikuti oleh huruf yang sama dalam kolom yang sama tidak berbeda nyata dengan uji BNT 5\%.

Pada Tabel 1, perlakuan media tanam tanah + pupuk kandang sapi dan pupuk hayati $15 \mathrm{~g} /$ tanaman menunjukkan yang paling tinggi. Hal ini diduga karena komposisi media (T1) tanah + pupuk kandang sapi mengandung kompos yang lebih banyak dan juga pupuk hayati mengandung mikroorganisme untuk menyuburkan tanah dan berperan positif untuk tanaman sehingga kebutuhan nutrisi terpenuhi. Unsur hara yang terdapat dalam pupuk kandang sapi yaitu $\mathrm{N}$, $P, K$ dan unsur hara lainnya yang diperlukan untuk pertumbuhan oleh tanaman,terutama unsur hara $\mathrm{N}$ yang digunakan untuk pertumbuhan vegetatif tanaman. Menurut Brady (1990) zat pengatur tumbuh seperti asam amino, auksin, vitamin, dan giberelin yang ada didalam bahan organik dapat memberikan keuntungan bagi pertumbuhan tanaman.

Pemberian pupuk kandang dapat memperbaiki tanah menjadi gembur sehingga mudah ditembus perakaran tanaman dan dapat mendorong berkembangnnya jasad renik tanah. Pupuk organik yang terdapat didalam pupuk kandang berperan memperbaiki sifat fisik, kimia dan biologii tanah serta untuk kesubran tanah. Menurut Simanungkalit (2001) bahwa pupuk hayati membantu tanaman menyediakan unsur hara bagi pertumbuhan oleh mikroba di dalam tanah. Mikroorganisme tersebut merombak bahan organik yang diberikan tanaman sehinga unsur hara tersebut tersedia oleh tanaman. 
Agroradix Vol. 3 No.1 Desember (2019)

ISSN : 2621-0665

\section{Diameter Bibit}

Hasil analisa ragam menunjukkan adanya interaksi antara perlakuan macam media tanam dan dosis pupuk hayati terhadap diameter bibit pengamatan umur 42 hst, 56 Tabel 2. Rata-rata Diameter Bibit pada Umur 42 Hst, 56 Hst, 70 Hst dan 84 Hst.

\begin{tabular}{|c|c|c|c|c|}
\hline \multirow{3}{*}{ Perlakuan } & \multicolumn{4}{|c|}{ Rata-rata Dimeter Batang pada Pengamatan } \\
\hline & \multicolumn{4}{|c|}{ Umur ke } \\
\hline & $42 \mathrm{Hst}$ & $56 \mathrm{Hst}$ & $70 \mathrm{Hst}$ & $84 \mathrm{Hst}$ \\
\hline Tanah,pupuk hayati $0 \mathrm{~g} /$ tanaman & 0,49 de & $0,60 \mathrm{de}$ & 0,67 cde & 0,74 bcde \\
\hline Tanah,pupuk hayati $10 \mathrm{~g} /$ tanaman & 0,52 cde & $0,58 \mathrm{e}$ & 0,66 de & 0,72 bcde \\
\hline Tanah,pupuk hayati $15 \mathrm{~g} /$ tanaman & 0,50 de & 0,59 de & $0,64 \mathrm{e}$ & 0,71 de \\
\hline Tanah,pupuk kandang sapi,pupuk hayati $0 \mathrm{~g} /$ tanaman & $0,53 \mathrm{~cd}$ & $0,63 \mathrm{bcd}$ & $0,72 \mathrm{bc}$ & 0,76 bcd \\
\hline Tanah,pupuk kandang sapi,pupuk hayati $10 \mathrm{~g} /$ tanaman & $0,55 \mathrm{bc}$ & $0,66 \mathrm{ab}$ & $0,73 a b$ & 0,77 bc \\
\hline Tanah,pupuk kandang sapi,pupuk hayati $15 \mathrm{~g} /$ tanaman & 0,62 a & $0,70 \mathrm{a}$ & $0,81 \mathrm{a}$ & $0,86 a$ \\
\hline Tanah,pasir,pupuk kandang sapi, pupuk hayati $0 \mathrm{~g} /$ tanaman & $0,55 \mathrm{bc}$ & $0,64 \mathrm{bc}$ & 0,67 cde & 0,72 bcde \\
\hline Tanah,pasir,pupuk kandang sapi,pupuk hayati $10 \mathrm{~g} /$ tanaman & $0,53 \mathrm{~cd}$ & $0,63 \mathrm{bcd}$ & $0,71 \mathrm{bcd}$ & $0,76 \mathrm{bcd}$ \\
\hline Tanah,pasir,pupuk kandang sapi,pupuk hayati 15 g/tanaman & $0,58 \mathrm{ab}$ & $0,66 \mathrm{ab}$ & $0,73 b$ & $0,78 \mathrm{~b}$ \\
\hline Total & 0,04 & 0,03 & 0,05 & 0,05 \\
\hline
\end{tabular}

Keterangan : Angka-angka yang diikuti oleh huruf yang sama dalam kolom yang sama tidak berbeda nyata dengan uji BNT 5\%.

Pada tabel 2, perlakuan media tanam tanah + pupuk kandang sapi dan pupuk hayati $15 \mathrm{~g} /$ tanaman menunjukkan nilai yang paling tinggi. Hal ini dikarenakan pemberian bahan organik dengan pertandingan 1 tanah : 1 bahan organik (pupuk kandang sapi) dapat meningkatkan aktivitas biologi, memperbaiki struktur tanah, meningkatkan kemampuan tanah menyimpan air, meningkatkan ketersedian hara di dalam tanah, mengurangi fiksasi fosfat pada tanah masam sehingga pertumbuhan tanaman untuk pembentukan batang menjadi normal. Jika suhu tanah/media tumbuh rendah maka pemberian bahan organik pada petak percobaan dapat ditingkatkan sehingga penggunanan bahan organik dapat menyamai kondisi lingkungan untuk pertumbuhan diameter bibit tanaman. pada

Tabel 3. Rata-rata Jumlah Jumlah Anakan

\begin{tabular}{lc}
\hline \multicolumn{1}{c}{ Perlakuan } & Rata-rata Jumlah Anakan \\
\hline Tanah & $1,98 \mathrm{~b}$ \\
Tanah + Pupuk kandang Sapi & $2,96 \mathrm{a}$
\end{tabular}

proses dekomposisi oleh pupuk hayati berbagai unsur hara di dalam tanah akan terlepas secara berangsur-angsur terutama unsur hara Nitrogen dan Fosfor. Hakim et al., (1986) Peranan unsur hara mikro dan makro dalam tanaman mendukung pertumbuhan serta memperlancar serapan hara bagi tanaman. Ditambahkan Brady dan Buckman (1982) pembentukan klorofil, sintesa protein dan merangsang pertumbuhan vegetatif tanaman sangat membutuhkan unsur hara $\mathrm{N}$ dan Fe terutama dalam pembentukan diameter bibit.

\section{Jumlah Anakan}

Hasil analisa ragam menunjukkan adanya hasil perbedaan nyata pada perlakuan macam media tanam terhadap jumlah anakan. Rata-rata jumlah anakan terdapat pada Tabel 3. hst, 70 hst dan 84 hst. Sedangkan pada pengamatan umur 14 hst dan 21 hst tidak terdapat interaksi. Rata-rata diameter bibit terdapat pada Tabel 2. 
Agroradix Vol. 3 No.1 Desember (2019)

ISSN : 2621-0665

Tanah + pupuk kandang sapi + pasir

$2,20 \mathrm{~b}$

BNT 5\% 0,50

Keterangan : Angka-angka yang diikuti oleh huruf yang sama dalam kolom yang sama tidak berbeda nyata dengan uji BNT 5\%.

Pada tabel 3, menunjukkan bahwa hasil tertinggi terdapat pada perlakuan media tanam tanah + pupuk kandang sapi. Hal ini dikarenakan pupuk kandang sapi mampu mengubah struktur tanah lebih gembur sehingga pertumbuhan jumlah anakan lebih leluasa berkembang dan memudahkan untuk menyerap unsur hara yang telah diberikan oleh pupuk kandang sapi, sejalan dengan pendapat Leiwakabessy (2003) bahwa penambahan pupuk kandang kotoran sapi dapat meningkatkan pertumbuhan dan produksi, karena pupuk kandang kotoran sapi cepat terurai sehingga mudah diserap untuk pertumbuhan tanaman tebu.

Pengaruh peningkatan kadar $\mathrm{P}$ dalam tanah yang tinggi dipengaruhi oleh media tanam dengan menggunakan pupuk kandang Tabel 4. Rata-rata Bobot Segar Bibit (g).

\begin{tabular}{lc}
\hline \multicolumn{1}{c}{ Perlakuan } & Rerata \\
\hline Tanah & $19,64 \mathrm{~b}$ \\
Tanah + Pupuk kandang Sapi & $21,67 \mathrm{a}$ \\
Tanah + pupuk kandang sapi + pasir & $20,53 \mathrm{ab}$ \\
\hline \multicolumn{1}{c}{ BNT 5\% } & 1,45 \\
\hline Kontrol & $19,44 \mathrm{~b}$ \\
Pupuk hayati 10 g/tanaman & $20,62 \mathrm{ab}$ \\
Pupuk hayati 15 g/tanaman & $21,78 \mathrm{a}$ \\
\hline \multicolumn{1}{c}{ BNT 5\% } & 1,45 \\
\hline
\end{tabular}

Keterangan: Angka-angka yang diikuti oleh huruf yang sama dalam kolom yang sama tidak berbeda nyata dengan uji BNT 5\%.

Pada Tabel 4, perlakuan media tanam tanah + pupuk kandang sapi dan menunjukkan nilai yang paling tinggi. Perlakuan macam media tanam dan pemberian dosis pupuk hayati yang berbeda menunjukkan pengaruh nyata terhadap bobot segar bibit tebu. Dengan perlakuan media tanam tanah + pupuk kandang sapi dan pemberian pupuk hayati $15 \mathrm{~g} /$ tanaman dapat meningkatkan kesuburan tanah karena bakteri yang terdapat dalam pupuk kandang sapi. Begitu juga kandungan $\mathrm{N}$ yang tinggi pada pupuk kandang dapat memacu laju pertumbuhan jumlah anakan. Nitrogen adalah unsur hara utama untuk tanaman, yang umumnya diperlukan pada vase vegetatif untuk pertumbuhan tanaman tebu seperti akar, batang, daun. Lakitan (2000) bahwa pembentukan dan pertumbuhan vegetatif tanaman seperti akar, batang, daun memerlukan unsur hara Nitrogen sebagai penyusun asam amino.

\section{Bobot Segar Bibit}

Hasil analisa ragam menunjukkan adanya hasil perbedaan nyata pada perlakuan macam media tanam dan dosis pupuk hayati terhadap bobot segar bibit. Rata-rata bobot segar bibit terdapat pada Tabel 4. sapi dan pupuk hayati tersebut dapat bekerja maksimal dalam merombak dan memfasilitasi asupan unsur hara yang dibutuhkan tanaman.

Kelebihan pupuk kandang sapi dapat membantu strutur tanah menjadi lebih baik untuk perkembangan akar tanaman dan daya ikat air, selain itu mampu memperbaiki kehidupan organisme dalam tanah. Ketersediaan air dan kompos dalam tanah dapat mempengaruhi perkembangan organ tanaman (daun, akar, dan batang) yang 
Agroradix Vol. 3 No.1 Desember (2019)

ISSN : 2621-0665

berhubungan dengan proses sel tanaman untuk membesar. Bobot segar adalah cerminan dari kandungan air yang terkandung dalam tanaman. Tanaman tebu merupakan jenis kaktus yang cadangan makan terdapat pada bagian batang, dan menggunakan batang sebagai alat untuk melakukan proses fotosintesis. Dalam pupuk hayati dapat menyediakan $\mathrm{NH} 3$ yang selanjutnya ditransformasikan menjadi NH4+ dan NO3untuk diserap tanamanuntuk peningkatan bobot segar tanamn tebu karena mengandung bakteri pemfiksasi N. Pupuk hayati membantu proses dekomposisi,

Tabel 5. Rata-rata Bobot Kering Bibit (g)

\begin{tabular}{|c|c|}
\hline Perlakuan & Rerata \\
\hline Tanah & $9,58 b$ \\
\hline Tanah + Pupuk kandang Sapi & $11,04 \mathrm{a}$ \\
\hline Tanah + pupuk kandang sapi + pasir & $10,36 a b$ \\
\hline BNT 5\% & 0,94 \\
\hline Kontrol & $9,53 \mathrm{~b}$ \\
\hline Pupuk hayati $10 \mathrm{~g} /$ tanaman & $10,42 a b$ \\
\hline Pupuk hayati $15 \mathrm{~g} /$ tanaman & $11,02 \mathrm{a}$ \\
\hline BNT 5\% & 0,94 \\
\hline
\end{tabular}

Keterangan : Angka-angka yang diikuti oleh huruf yang sama dalam kolom yang sama tidak berbeda nyata dengan uji BNT 5\%.

Tabel 5, perlakuan media tanam tanah + pupuk kandang sapi (T1) dan pupuk hayati $15 \mathrm{~g} /$ tanaman menunjukkan nilai yang paling tinggi. Pertumbuhan vegetatif tanaman yang baik pada perkembangan sistem perakaran akan mempengaruhi produksi tanaman. terbentuk mencerminkan banyaknya fotosintat yang dihasilkan fotosintesis. Pupuk organik dianggap sebagai pupuk yang lengkap, karena selain menghasilkan unsur hara juga meningkatkan aktivitas mikroorganisme di dalam tanah. Azotobacter dalam pupuk hayati dapat mengefisiensikan penggunaan pupuk anorganik. Simanungkalit (2001), mikroorganisme yang terdapat di dalam pupuk hayati akan membantu tanaman dalam memfasilitasi atau menyediakan unsur hara yang dibutuhkan tanaman. Hal ini karena dalam pupuk hayati yang digunakan mempunyai kandungan bahan organik yang didalam tanah unsur hara akan terlepas terutama unsur hara Nitrogen dan Fosfor. Hasil penelitian Susilawati et.al (2012) yang mendapati bahwa banyaknya populasi mikroorganisme dalam tanah mempengaruhi secara nyata kesuburan tanah tersebut.

\section{Bobot Kering Bibit}

Hasil analisa ragam menunjukkan adanya hasil perbedaan nyata pada perlakuan macam media tanam dan dosis pupuk hayati terhadap bobot kering bibit. Rata-rata bobot skering bibit terdapat pada Tabel 5.
Tanaman yang meperoleh hara cukup dan maksimal sesuai dengan yang dibutuhkan oleh tanaman akan dapat meningkatkan hasil bobot kering yang optimal.

Laju fotosintesis sangat tergantung oleh bahan kering karena bobot kering yang berasal dari bahan pembawanya, meskipun jumlahnya tidak banyak, hal ini menyebabkan terjadinya penambahan kadar bahan organik dalam tanah.

\section{SIMPULAN}

Hasil penelitian didapat bahwa hasil terbaik terdapat pada perlakuan media tanam tanah + pupuk kandang sapi dan pupuk hayati $15 \mathrm{~g} /$ tanaman dibandingkan dengan perlakuan yang lainnya. 
ISSN : 2621-0665

\section{DAFTAR PUSTAKA}

Brady dan Buckman. 1982. Ilmu Tanah. Bharata Karya Angkasa. Jakarta

Brady, N. C. 1990. The Nature and Properties of Soil. 10th Edition. Pp.621. Macmillan Publising Co., New York. Http://yagipray.Blogspot.com/2012/03/ bahan-organik.html. Diakses tanggal 18 Mei 2015.

Hakim N., N. Yusuf, A.M. Lubis., Nugroho. S.G., M.A. Diha, G.B. Hong, dan H.H. Bailey. 1986. Dasar - Dasar Ilmu Tanah. Universitas Lampung. Lampung.

Hanafiah, K. A. N, Napoleon. Ghofar. 2007. Biologi Tanah : Ekologi dan Makrobiologi Tanah : Edisi 1-2. PT. Rajawali Grafindo Persada, Jakarta

Khaswarina, 2011. Kelapa Sawit (Elaeis Guineensis Jacq) di Indonesia. Pusat Penelitian Perkebunan Marihat Bandar Kuala. Pematang

Lakitan,B. 2000. Fisiologi Tumbuhan dan Perkembangan Tanaman. Raja Grafindo. Jakarta

Leiwakabessy, F.M., U.M. Wahjudin dan Suwarno. 2003. Kesuburan Tanah. Departemen Ilmu Tanah. Fakultas Pertanian. Institut Pertanian Bogor. Bogor.

Mezuan, I.P. Handayani, E. Inoriah. 2002. Penerapan Formulasi Pupuk Hayati Untuk Budidaya Padi Gogo. Jurnal IImuIlmu Pertanian Indonesia. 4(1) : 27-34.

Primahandana dan Hendroko, 2008. Kadar gula dan Energi Hijau. Jakarta: penebar Swadaya.

Setyamidjaja. 2006. Budidaya Kelapa Sawit. Kanisium. Yogyakart Sriyanto, D., P. Astuti., dan A.P. Sujalu. 2015. Pengaruh Pupuk kandang Sapi Terhadap
Pertumbuhan dan Hasil Tanaman Terong Ungu dan Terong Hijau (Solanum Melongena L.). Jurnal Agrifor. 14(1):1-6.

Simanungkalit, R.D.M. 2001. Aplikasi pupuk hayati dan pupuk kimia: suatu pendekatan terpadu. BuletinAgro-Bio4 (2):56-61

Sutejo, M.M. dan A. G. Kartasapoetra. 1992. Pupuk dan Cara Pemupukan. Bina Aksara, Jakarta. $176 \mathrm{hlm}$.

Sutedjo. 1994. Pupuk dan Cara Pemupukan. Rineka Cipta. Jakarta.

Susilawati, S. 2012. Kualitas Mikrobiologis Sosiss fermentasi yang diberi Probiotik Lactobacillus plantarum atau Lactobacillus acidophilus 2B4. Skripsi. Departemen Ilmu Produksi dan Teknologi Peternakan, Fakultas Peternakan, Institut Pertanian Bogor. Bogor. 